\title{
MonikasviGIS: Paikkatietopohjainen menetelmä viljelykasvien sijoitteluun
}

\author{
Arsi Ikonen ${ }^{1)} \&$ Hanna Huitu ${ }^{2)}$ \\ ${ }^{1)}$ MTT (Maa- ja elintarviketalouden tutkimuskeskus) Ympäristöntutkimus, 31600 Jokioinen, \\ arsi.ikonen@mtt.fi \\ ${ }^{2)}$ MTT (Maa- ja elintarviketalouden tutkimuskeskus) Ympäristöntutkimus, 31600 Jokioinen, \\ hanna.huitu@mtt.fi
}

\section{Tiivistelmä}

Monikasvi-hankkeen osahankkeessa MonikasviGIS kehitettiin paikkatietopohjaista menetelmää tilan ympäristövaihtelun spatiaaliseen mallintamiseen ja tähän perustuvien lohkottaisten viljelysuosituskarttojen tuottamiseen, kun eri viljelykasvien ympäristövaikutukset ja -vaatimukset tunnetaan. Osaprojektin pilottiluonteen vuoksi ongelmaa rajattiin niin, että mallinnettiin vain lohkojen fosforikuormituspotentiaali ja biodiversiteettitaso, joihin annetut viljelysuositukset perustettiin. Tämä malli ei luonnollisestikaan sisällä kaikkia todellisessa viljelykasvin valintatilanteessa relevantteja tekijöitä. Ongelman yksinkertaistus oli kuitenkin perusteltu ratkaisu menetelmän kehittämisen alkuvaiheessa. Jatkossa malliin voidaan liittää lisämoduuleina myös kasvien kasvupaikkavaatimuksiin ja kasvuedellytysten spatiaaliseen vaihteluun perustuvat kasvien lohkokohtaiset sato- ja tuottoennusteet viljelysuositusten perusteeksi.

Menetelmällä on mahdollista luoda erilaisia viljelysuosituksia riippuen siitä, millaiset painokertoimet annetaan fosforikuormituksen vähentämiselle ja monimuotoisuuden kehittämiselle. Esimerkkinä luotiin 3 viljelysuositusta pilottialueeksi valitun Lintupajun tilan lohkoille. Strategiassa A pyrittiin kasvilajien sijoittelulla pelkästään minimoimaan pelloilta tulevaa fosforikuormitusta. Strategiassa B kasvit sijoitettiin yksinomaan biodiversiteetin näkökulmasta siten, että diversiteettiin suotuisimmin vaikuttavia kasvilajeja suositeltiin lohkoille, joiden nykyinen diversiteettitaso ennustettiin viljelyhistoriaan perustuen alhaisimmaksi. Yhdistelmästrategiassa $\mathrm{C}$ sekä fosforikuormituksen minimoinnille että biodiversiteetin kehittämiselle kummallekin annettiin $50 \%$ painoarvo. Viljelysuosituskartat odotetusti erosivat hyvin paljon vaihtoehtoisissa strategioissa.

MonikasviGIS -menetelmän kannalta keskeinen paikkatietotekniikka on pisteaineistojen yleistäminen koko tilan alueen kattavaksi 3-ulotteiseksi rasteripinnaksi, jonka pikselien kolmas eli z-koordinaatti kuvaa tarkasteltavan muuttujan arvoa kullekin pikselille. Yleistämällä luotuja 3D-rasteripintoja voidaan edelleen asettaa päällekkäin, jonka jälkeen kuva-alueen jokaiselle pikselille voidaan rasterilaskennassa sopivalla funktiolla määrittää tasojen yhdistelmänä saatava arvo. Näitä yhdistelmärasteripintoja voidaan edelleen leikata peltolohkojen vektorimuotoisilla rajoilla ja laskea lohkokohtaisesti esimerkiksi pikseleiden z-koordinaatin keskiarvo, joka voidaan antaa vektorimuotoiseen lohkoraja-aineistoon lohkopolygonien attribuutti- eli ominaisuustiedoksi. Tämän attribuutin perusteella voidaan yksinkertaisilla loogismatemaattisilla säännöillä määrätä suositeltavin viljelykasvi kullekin peltolohkolle, kun kasvilajien biologiset ominaisuudet tunnetaan.

MonikasviGIS -menetelmän kehittämiseen todelliseksi tilatason työvälineeksi on hyvät edellytykset, sillä tilan ympäristövaihtelun spatiaalisen mallinnuksen vaatimat syöttötiedot pääosin jo nykyiselläänkin löytyvät tiloilta tai ovat kohtuullisilla panostuksilla hankittavissa. Tilatasolla menetelmä käytännössä edellyttää maalaji- ja viljavuusanalyysituloksia GPS-paikannetuista pisteistä lohkoilla sekä viljelyhistoriatietoja kulmistaan GPS-paikannetuilta kasvulohkoilta. Peltojen kaltevuus voidaan tulevaisuudessa mallintaa tekeillä olevan tarkan kansallisen korkeusrasteriaineiston pohjalta. Toisaalta MonikasviGIS menetelmän jatkokehittely edellyttäisi nykyistä tarkempaa, vertailevaa aineistoa varsinkin eri kasvilajien vaikutuksista peltoympäristön kokonaisbiodiversiteettiin.

Asiasanat: Paikkatieto, GIS, erikoiskasvit, peltoviljely, monimuotoisuus, biodiversiteetti, fosforikuormitus 


\section{Johdanto}

Viljelykasvien tarkoituksenmukaisessa sijoittelussa peltolohkoille tulisi samanaikaisesti kyetä huomioimaan useita eri tekijöitä. Eri kasvilajit käyttävät ja sitovat maaperän ravinteita vaihtelevalla tehokkuudella, joten eri kasvilajit myös estävät pelloilta vesistöihin tulevaa hajakuormitusta eri tavalla. Mikäli kasvilajien viljelymenetelmien yksityiskohdat kuten kylvöaika ja kasvuston kehittymisen fenologia eroavat, myös nämä tekijät voivat aiheuttaa eroja siinä, kuinka suuressa määrin eri kasvilajit vähentävät vesistöjen ravinnekuormitusta. Useimmissa sisävesissä tärkein perustuotantoa rajoittava ravinne on fosfori, joten ravinnekuormituksen minimoinnin näkökulmasta viljelykasvit tulisi sijoittaa ensisijaisesti fosforikuormitusta tehokkaimmin vähentävällä tavalla.

Tutkimukset myös osoittavat, että eri peltokasvien merkitys ja arvo biodiversiteetin kannalta vaihtelee huomattavasti (Huusela-Veistola ym. 2004, M. Keskitalo ym. julkaisematon aineisto, A. Palojärvi ym. julkaisematon aineisto). Peltoympäristön eliöryhmien monimuotoisuus ja runsaus riippuvat lohkon viljelykasvista. On kuitenkin huomattavan vaikeaa määrittää kasvilajeille yksiselitteistä kokonaisbiodiversiteettiarvoa, koska tällaisen informaatiota tiivistävän ja kokoavan indeksin laskemisessa tulisi ottaa ekologisesti relevantilla painokertoimella huomioon kasvilajin vaikutus useiden erityyppisten eliöryhmien monimuotoisuuteen ja runsauteen. Jonkinlainen kasvilajikohtainen kokonaisbiodiversiteettiarvon estimaatti on kuitenkin välttämätön, jotta kasvilajit voitaisiin sijoitella biodiversiteetin kehittämisen kannalta tarkoituksenmukaisesti.

Edelleen kasvilajien tarkoituksenmukaisessa sijoittelussa peltolohkoille tulee huomioida kasvien kasvupaikkavaatimukset ja niiden toteutuminen eri peltolohkoilla. Tämä vaikuttaa sadon laatuun ja määrään, ja edelleen viljelyn taloudelliseen tulokseen. Kasvupaikkavaatimusten toteutumista arvioitaessa on samanaikaisesti huomioitava useiden tekijöiden (esim. maalaji, ravinteet ja kosteusolot) alueellinen vaihtelu tilan sisällä. Kaiken kaikkiaan viljelykasvien tarkoituksenmukainen sijoittelu tilan sisällä on selvästikin suhteellisen monimutkaista informaation analysointia ja yhdistelyä vaativa tehtävä.

Tietokonepohjaiset paikkatietomenetelmät (GIS) tarjoavat kehittyneet työkalut yllä kuvatun kaltaisten, useiden muuttujien alueelliseen vaihteluun liittyvien ongelmien ratkaisuun. GIS-menetelmissä voidaan ensinnäkin mallintaa kunkin yksittäisen muuttujan vaihtelua tilan sisällä yleistämällä lohkoille sijoitettujen näytepisteiden informaatio interpolatiivisilla laskentamenetelmillä kattamaan myös näytepisteiden välit eli koko tilan alue. Tuloksena syntyy kullekin muuttujalle 3-ulotteinen rasteripinta, jonka pikseleiden kolmas eli z-koordinaatti kuvaa tarkasteltavan muuttujan arvoa tietyssä kuva-alueen osassa. Tämä voidaan helposti visualisoida karttaesitykseksi, jossa z-koordinaattia vastaa pikselin väriarvo.

GIS-järjestelmissä voidaan asettaa useiden eri muuttujien 3D-rasteripintoja päällekkäin ja laskea tarkoituksenmukaisella funktiolla kullekin kuva-alueen pikselille tasojen yhdistelmäarvo, josta tulee uuden yhdistelmätason z-koordinaatti. Rasterimuotoista yhdistelmätasoa voidaan edelleen leikata vektorimuotoisilla peltolohkojen rajoilla ja laskea esimerkiksi lohkokohtainen keskiarvo pikseleiden zkoordinaatille. Tuloksena saadaan aineisto, jossa kuhunkin peltolohkopolygoniin liittyy attribuuttina yhdistelmätason z-koordinaattiarvojen alueen sisäinen keskiarvo. Kun tunnetaan kasvien biologiset ominaisuudet, voidaan tarkoituksenmukaisesti luotujen lohkojen attribuuttien pohjalta johtaa yksinkertaisilla matemaattis-loogisilla säännöillä lohkokohtainen viljelykasvisuositus.

\section{Aineisto ja menetelmät}

Tässä työssä valittiin MonikasviGIS -menetelmän kehittelyn pilottialueeksi MTT:n Jokioisten toimipaikan lähistöllä sijaitseva Lintupajun tila. Valinnan keskeisenä perusteena oli se, että po. alueelta oli MTT:n aiempiin tutkimuksiin liittyen kerätty paikannetuista pisteistä erittäin monipuolisesti tutkimusaineistoa, jonka pohjalta voitiin mallintaa useiden relevanttien muuttujien alueellista vaihtelua. Tarkastelualue käsitti yhteensä 16 peruslohkoa.

Koska kyseessä oli resursseiltaan hyvin rajattu projekti ongelman laajuuteen ja työn pioneeriluonteeseen nähden, myös ongelmanasettelua rajattiin todellista viljelykasvin valintatilannetta yksinkertai- 
semmaksi. Menetelmän kehittelyä varten Lintupajun tilalta mallinnettiin 2 keskeistä ympäristötekijää: lohkojen ennustettu fosforikuormituspotentiaali ja tilan viljelyhistoriaan perustuva ennuste biodiversiteetin alueellisesta vaihtelusta lohkoilla. Mallinnusten perusteella laadittiin viljelysuosituksia 9 kasvilajin sijoittamisesta lohkoille. Mallissa mukana olleet kasvilajit olivat: rehuohra, timotei, kinua, kitupellava, kumina, nokkonen, ruokohelpi, tattari ja öljypellava. Viljelysuosituksille asetettiin ehdoksi, että kutakin kasvilajia tuli viljellä vähintään yhdellä lohkolla. Koska lohkoja oli 16 kpl ja kasvilajeja 9 kpl, kussakin suosituksessa varattiin seitsemälle kasvilajille 2 lohkoa ja lopuille 2 kasvilajille kummallekin yksi lohko. Strategiassa A pyrittiin kasvilajien sijoittelulla pelkästään minimoimaan pelloilta tulevaa fosforikuormitusta. Strategiassa B kasvit sijoitettiin yksinomaan biodiversiteetin näkökulmasta siten, että kokonaisbiodiversiteettiin suotuisimmin vaikuttavia kasvilajeja suositeltiin lohkoille, joiden nykyinen biodiversiteettitaso ennustettiin viljelyhistoriaan perustuen alhaisimmaksi. Yhdistelmästrategiassa $\mathrm{C}$ sekä fosforikuormituksen minimoinnille että biodiversiteetin kehittämiselle kummallekin annettiin $50 \%$ painoarvo.

Lohkojen fosforikuormituspotentiaalin mallinnus perustui Uusitalon ym. (2001) kehittämään fosforikuormitusindeksiin, muuttujista huomioitiin maalaji, pinnan kaltevuus sekä maalajin, multavuuden ja fosforipitoisuuden perusteella määräytyvä fosforiluokka. Työhön sisällytettyjen kasvien fosforinsidontakykyä (mg/g korjattavaa kasvibiomassaa) ja juuristobiomassaa oli selvitetty Monikasvi-hankkeen muissa osahankkeissa (M. Keskitalo ym. julkaisematon aineisto). Juuristobiomassalla oletettiin olevan merkistystä irtonaisen maa-aineksen sitomisessa.

Lintupajun viljelyhistoriatiedot oli jo aiemmin MTT:n GIS-ryhmän toimesta siirretty digitaalimuotoon paikkatietojärjestelmään. Aineisto käsittää monipuolisesti erilaista informaatiota viljelymenetelmistä jne., mutta tässä työssä viljelyhistoriatiedoista huomioitiin kunkin lohkon viljelykasvilajisto viimeisen 10 vuoden ajalta sekä lohkorajoille tehtyjen 5 metrin puskureiden ja lohkojen kokonaispinta-alojen perusteella lasketut reunan osuudet koko lohkojen pinta-aloista. Oletettiin, että mitä enemmän lohkon alasta oli reunaa ja mitä monipuolisempi viljelykasvilajisto, sitä korkeammaksi lohkon nykyinen biodiversiteettitaso voidaan ennustaa.

Kasvilajien biodiversiteettiarvon laskemisessa yhdistettiin Monikasvi-hankkeen muiden osahankkeiden tuottamaa aineistoa maaperämikrobeiden (aktinobakteerit ja mykoritsat) runsaudesta (A. Palojärvi ym. julkaisematon aineisto) sekä pölyttäjähyönteisfaunan diversiteetistä (M. Keskitalo ym. julkaisematon aineisto) eri kasvilajien viljelylohkoilla. Tämä ei tietenkään ole kattava arvio eri kasvilajien biodiversiteettiarvoista, mutta se kuitenkin soveltui MonikasviGIS -menetelmän alustavan kehittelyn lähtökohdaksi.

\section{Tulokset}

Pilottiprojektin rajattuna tavoitteena oli kehittää menetelmiä paikkatietopohjaiseen viljelykasvien sijoitteluun. Kuvassa 1 on rinnakkain esitetty strategioilla B ja C Lintupajun alueelle laaditut lohkokohtaiset kasvilajisuositukset. Kasvilajien sijoittelusuositus on selvästi erittäin riippuva siitä, millaiset painoarvot annettiin fosforikuormituksen minimoinnille ja toisaalta biodiversiteetin maksimoinnille. 

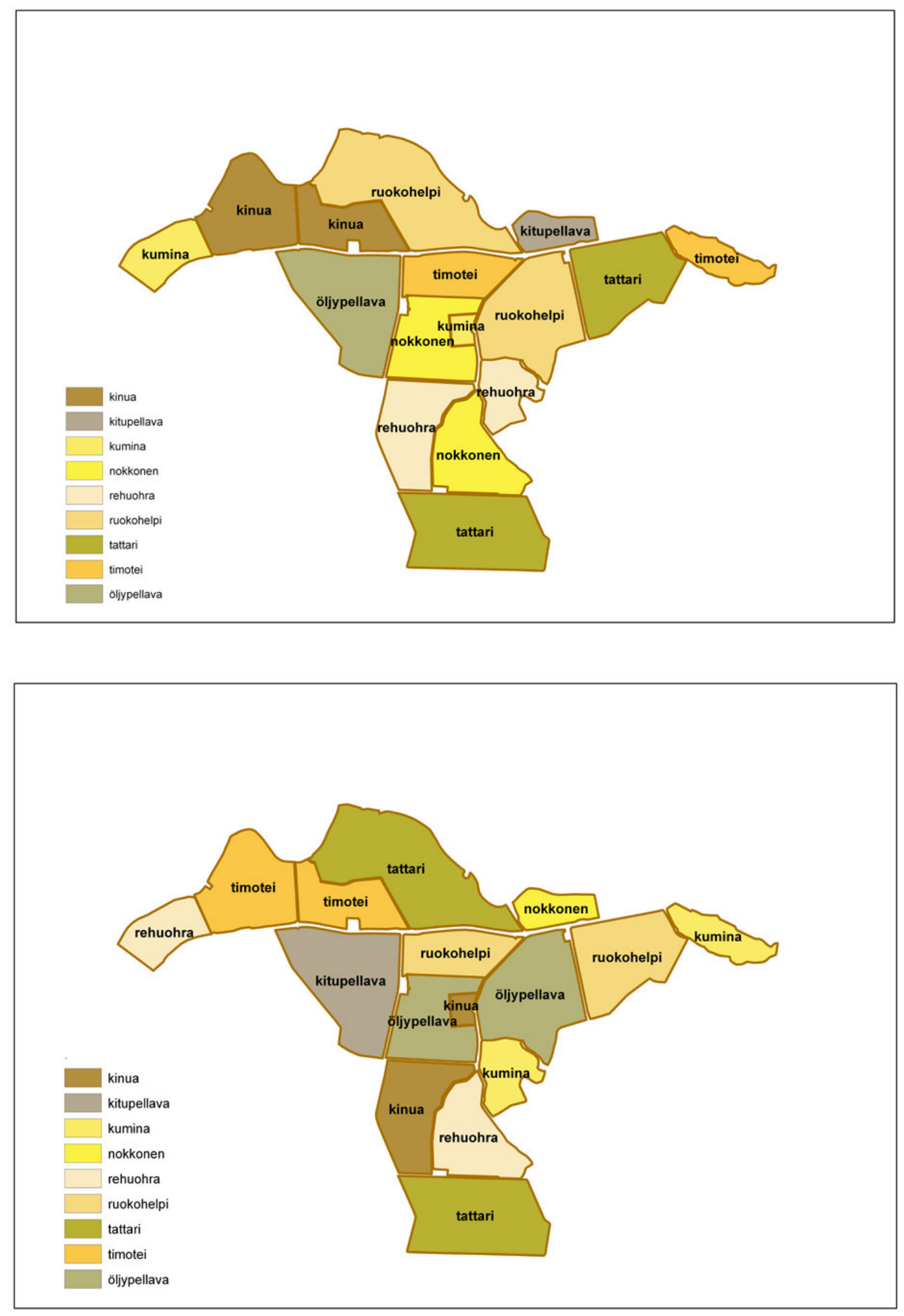

Kuva 1. Lintupajun peltolohkojen kasvisuositukset strategioiden B (ylempi) ja C (alempi) mukaan. 


\section{Tulosten tarkastelu}

Viljelykasvien tarkoituksenmukainen sijoittelu edellyttää monien eri muuttujien alueellisen yhteisvaihtelun ja suuren informaatiomäärän analysointia, joten tietokonepohjaiset paikkatietojärjestelmät tarjoavat parhaat työkalut vaihtelun mallintamiseen ja siihen perustuvien lohkottaisten viljelykasvilajisuositusten tuottamiseen. MonikasviGIS-menetelmän osalta keskeisiä paikkatietotekniikoita ovat pisteaineistojen yleistäminen 3D-rasteripinnoiksi ja rasterilaskenta.

MonikasviGIS-osahankkeessa Lintupajun alueelle laaditut viljelykasvisuositukset erosivat huomattavasti riippuen siitä, millainen painoarvo annettiin fosforikuormituksen minimoinnille ja toisaalta biodiversiteetin kehittämiselle. Mikäli malliin sisällytettäisiin vielä kasvilajien kasvuedellytysten mallinnus ja siihen perustuvat sato- ja tuottoennusteet, mahdollisten viljelysuositusvaihtoehtojen määrä kasvaisi entisestään. Niinpä MonikasviGIS-menetelmän kehittelyn osalta on varsin keskeistä miettiä, millä perusteilla viljelysuositusten pohjana olevien tekijöiden painoarvot määrätään.

MonikasviGIS -menetelmän kehittämiseen todelliseksi tilatason työvälineeksi on hyvät edellytykset, sillä tilansisäisen ympäristövaihtelun mallinnuksen vaatimat syöttötiedot pääosin jo nykyiselläänkin löytyvät tiloilta tai ovat kohtuullisilla panostuksilla hankittavissa. Tilatasolla menetelmä käytännössä edellyttää maalaji- ja viljavuusanalyysituloksia GPS-paikannetuista pisteistä lohkoilla sekä viljelyhistoriatietoja kulmistaan GPS-paikannetuilta kasvulohkoilta. Peltojen kaltevuus voidaan tulevaisuudessa mallintaa tekeillä olevan tarkan kansallisen korkeusrasteriaineiston pohjalta.

Menetelmää voidaan täsmentää ja kehittää useilla tavoilla. Lohkojen fosforikuormituspotentiaalin mallinnusta voidaan esimerkiksi tarkentaa sisällyttämällä malliin mukaan tiedot lohkojen lannoitushistoriasta ja salaojaverkostosta (Gburek ym. 2000, Uusitalo ym. 2001, Djodjic ym. 2002). Tuotetun mallin toimivuuden tutkiminen edellyttäisi mallin lohkokohtaisen fosforikuormitusennusteen ja valumavesien fosforipitoisuuksien vertaamista (kts. Nyholm ym. 2003). Perusteellinen biodiversiteettimallinnus vaatisi pohjakseen erillisen tutkimuksen siitä, minkälainen riippuvuus viljelyshistoriamuuttujien ja lohkojen nykyisen biodiversiteettitason välillä vallitsee. Pilottivaiheessa viljelyshistoriamuuttujista valittiin menetelmän kokeilemiseksi ja sen perusteiden hahmottelemiseksi hyvin subjektiivisin perustein mukaan 10 viimeisen vuoden viljelykasvilajiston monimuotoisuus ja reunavyöhykkeen osuus lohkoilla. Se, kuinka hyvin tai huonosti nämä muuttujat ennustavat lohkojen nykyistä biodiversiteettitasoa, jäi pakostakin tämän viljelysuositusten tuottamiseen sopivien GIS-menetelmien peruskartoitukseen tähdänneen pienimuotoisen osahankkeen rajauksen ulkopuolelle.

\section{Kirjallisuus}

Djodjic, F., Montas, H., Shirmohammadi, A., Bergström, L. \& Ulén, B. 2002. A decision support system for phosphorus management at a watershed scale. J. Environ. Qual. 31: 937-945.

Gburek, W.J., Sharpley, A.N., Heathwaite, L. \& Folmar, G.J. 2000. Phosphorus management at the watershed scale: A modification of the phosphorus index. J. Environ. Qual. 29: 130-144.

Huusela-Veistola, E., Helenius, J., Kinnunen, H., Tiainen, J. \& Tiira, M. 2004. Viljelykasvustojen selkärangattomat eläimet. Teoksessa: Tiainen, J., Kuussaari, M., Laurila, I.P., Toivonen, T., Hallanaro, E.-L. \& Parkkinen, S. Elämää pellossa. Suomen maatalousympäristön monimuotoisuus. 366 s. Edita, Helsinki.

Nyholm, A.-M., Jansson, H., Puronummi, N., Nyholm, R., Ala-Opas, P., Hakala, I., Huitu, E., Mäkelä, S., Tulonen, T. \& Arvola, L. 2003. Valuma-alueen ja vesistön välisen vuorovaikutuksen arviointi. Maa- ja elintarviketalous 38. MTT, Jokioinen.

Uusitalo, R., Tuhkanen, H.-R., Yli-Halla, M. 2001. Viljelijöille työkalu fosforikuormituksen hallintaan. Ympäristö ja terveys 32: 70-73. 